\title{
オノマトペをもちいたストループ効果の検証
}

\author{
$\bigcirc$ 矢口幸康 ${ }^{1} \cdot$ 谷中久和 ${ }^{2}$ \\ $\left({ }^{1}\right.$ 聖徳大学・ ${ }^{2}$ 鳥取大学) \\ キーワード :オノマトペ、ストループ効果、カラーイメージ
}

\section{Verification of stroop effect using onomatopoeia}

Yukiyasu YAGUCHI ${ }^{1}$, Hisakazu YANAKA ${ }^{2}$

( ${ }^{1}$ Seitoku Univ., ${ }^{2}$ Tottori Univ)

Key Words: Onomatopoeia,StroopEffect,ColorImage

\begin{abstract}
目 的
擬音語・擬態語（以下オノマトペ）は感覚や情動と 強く関連する語であり（苧阪, 1999 ; 矢口, 2012)，そ の高いイメージ喚起力は諸分野から注目されている。 近年では、オノマトペが喚起するカラーイメージに注 目した研究が増加しており、牧野 (2009：2012) はオノ マトペが色彩イメージと密接に関係することを報告し ている。オノマトペが視覚的イメージを強く喚起する ものであることは知られているが、色彩イメージをど の程度の強度で想起させるか検討した例は少ない。

矢口（2015）はオノマトペを利用した情動ストルー プ実験において、オノマトペを提示した場合にも情動 価が高い単語（殺害、死亡など）と同様に提示色の同 定反応に遅延が発生することを報告している。この結 果はオノマトペが情動語と同程度の情動イメージを喚 起しうることを示唆したものである。ストループ実験 という同一パラダイムにおいて、刺激語を変えたとし ても同様の遅延が発生した場合、異なる刺激語同士で 似通った情報処理がなされている可能性は高い。

そこで本研究は、矢口（2015）を参考にオノマトペ を刺激語とするストループ課題を実施する。通常の色 単語を利用したストループ効果のパラダイムにおいて

「刺激語をオノマトペとした場合にも同様の遅延が発 生する」という仮説を設定し、オノマトペが色単語視 認時と等しい色彩イメージを喚起しているか探ること が目的である。
\end{abstract}

\section{方 法}

参加者 大学生大学院生 40 名 (男性 20 名: 女性 20 名、 平均年齢 21.61 歳 SD1.91)

刺激語 牧野（2012）において心理 4 原色を強く連想 すると報告されている色彩オノマトペ 4 語を刺激語と してもちいた。その内容は、「メラメラ (赤)、ザーザ 一 (青)、ザワザワ (緑)、キラキラ (黄)」であった。 4 語のオノマトペを 4 色で表示し合計 16 語を提示した。 手続き 実験は PC をもちいて行い、刺激語提示および 反応計測はPsychoPy2 によって制御された。4 色いずれ かで表示された刺激語は 1 語ずつモニター中央に表示 され、参加者は素早く表示色と一致する色キーを押す ことが求められた。提示画面の背景は灰色であった。

個人内誤差の影響を軽減するため刺激語は 3 回ずつ 提示され参加者は合計 48 試行 $(4$ 語 $\times 4$ 色 $\times 3$ 回 $)$ に参 加した。刺激の提示順序はランダム化された。

また、同様の手続きで刺激語を色単語（赤青緑黄） にしたカラーストループ実験も実施した。カラースト ループとオノマトペストループの実施順序はカウンタ ーバランスをとった。

\section{結 果と考 察}

オノマトペストループ課題およびカラーストループ 課題においてそれぞれ取得した 4 層データ $(40$ 名 $\times 4$ 語 $\times 4$ 色 $\times 3$ 試行) を平均值化し、単語と表示色の一致不 一致別に分類した Figure1,2)。

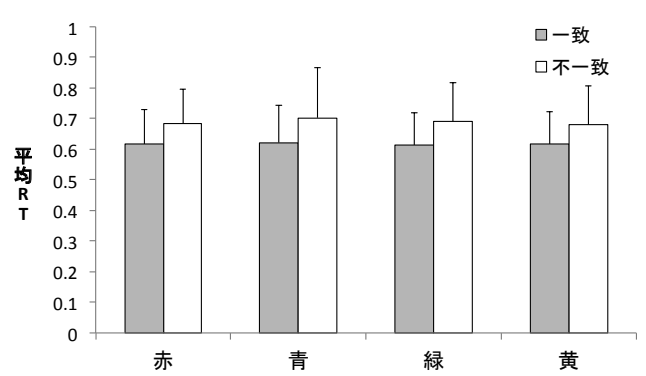

Figure1 カラーストループ課題平均 RT

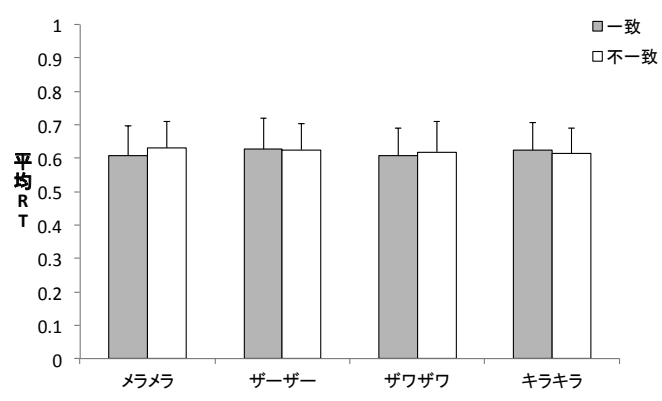

Figure2 オノマトペストループ課題平均 RT

各単語における一致不一致の RT を比較したところ、 カラーストループでは 4 つ色単語全てにおいて不一 致条件の有意な遅延が示され効果量の強さも認められ た $(t s>3.48, p s<.01, d s>.54)$ 。また、赤と黄において不 一致条件の誤答率が有意に高かった $(t s>3.59, p s<.01$, ds>. 47)。一方、オノマトペストループにおいては、メ ラメラ提示時のみ有意な遅延が示され $(t=2.1$

$0, p<.05, d>.33)$ 、不一致条件の誤答率の高さが示され た $(t=2.47, p<.05, d>.37)$ 。

カラーストループ効果が発生したことから、実験パ ラダイムおよび参加者の反応が適切であったことがわ かる。メラメラにおいてのみストループ効果が発生し たことから、オノマトペの色イメージ喚起は安定した ものではなく、単語によってその作用が異なることが 推測される。 